\title{
MANAGEMENT DECISIONS SUPPORT SYSTEM FOR RHODEUS AMARUS (BLOCH, 1782) SPECIES POPULATIONS IN OLTUL MIJLOCIU - CIBIN - HÂRTIBACIU NATURA 2000 SITE (ROMANIA)
}

\author{
Doru, BĂNĂDUC ${ }^{1}$, Ioana-Cristina, CISMAȘ² ${ }^{2}$ Teodora, TRICHKOVA ${ }^{3}$ and Angela, CURTEAN- \\ BĂNĂDUC ${ }^{4}$ \\ 1 "Lucian Blaga" University of Sibiu, Sibiu, Romania, ad.banaduc@yahoo.com \\ 2 "Lucian Blaga" University of Sibiu, Sibiu, Romania, cristha_83@yahoo.com \\ 3 Bulgarian Academy of Sciences, Sofia, Bulgaria, trichkova@zoology.bas.bg \\ 4 "Lucian Blaga" University of Sibiu, Sibiu, Romania, angela.banaduc@ulbsibiu.ro
}

\begin{abstract}
The main threats to the Rhodeus amarus (Bloch, 1782) populations in the Natura 2000 site Oltul Mijlociu - Cibin Hârtibaciu are the hydro technical modifications of the riverbeds, chemical pollution and poachery. ADONIS:CE is used in general for modeling business processes, but here was used in ecology/biology domain. The authors obtained a Rhodeus amarus model which included all the habitat species requirements, the indicators that provide favourable conservation status and the existing threats and pressures. The maintaining of the minor riverbed morphodynamics is very important - the meanders presence is very important for the local molluscs which are living in the inner $U$ shape parts of the river. The places, where the sediments (sand, mud) are relatively stable, provide suitable habitats for molluscs important for the breeding of Rhodeus amarus. The maintaining of the actual regimes of liquid flows and oxygenation, and the avoidance of increasing of the sediments deposition rate in the water are necessary also for those molluscs species presence conservation. The extraction of sediments in these rivers should be made in correspondence with their natural rate of refilling and at sites at a distance of minimum five kilometres from each other.
\end{abstract}

KEY WORDS: Rhodeus amarus, threats, pressures, habitat fish species requirements, management process modelling.

\section{INTRODUCTION}

Romania as all European Union member states, have to assure a strict protection of the species listed in the Habitats Directive Annex 2 and not allow the deterioration of ecological status induced by human activities (*, 1992).

The Natura 2000 sites in Romania, including also those for fish species protection, were proposed for conservation of their ecological status. The proposals were based on specific criteria, such as: typical natural habitats, well preserved, stable and healthy fish populations, favorable geographical position, and relatively low human impact. In general, there are few major ways, through which the Natura 2000 network initiative can improve the EU member states nature protection: the extension of the natural areas' surface, institutional capacity building, raising awareness, as well as the implementation of correct management plans for the protected areas. (Bănăduc, 2001, 2007a, 2008a, b, 2010, 2011, Bănăduc et. al., 2012, CurteanBănăduc and Bănăduc, 2008).

One of the fish species of Community interest is the European bitterling, Rhodeus amarus (Bloch, 1782). These species individuals are living in fresh and standing or slow flowing water, preferably among macrophytic vegetations, over sand and muddy bottom. The species achieves sexual maturity at age one and at about 30-35 $\mathrm{mm}$ standard length. The spawning occurs in the end of April till August and it is closely related with freshwater mussels (Unio and/or Anodonta). (Bănărescu 1964; Bănărescu and Bănăduc, 2007). During the spawning season, males develop bright nuptial coloration and defend area around mussel, while females develop long ovipositors using to deposit eggs onto the gills through the exhalant siphon. Males fertilize the eggs by releasing sperm into the inhalant siphon of the mussel which carries the sperm to the eggs (Smith et al., 2004). Embryos reside inside the mussel for approximately one month up to active swimming capacity (Aldridge, 1999). The species feeds mainly on filamentous green algae, diatoms and plant detritus, and rarely on crustaceans and insect larvae. It has a short life span; maximum reported age is five years. In the population, males usually predominate over females, especially on the spawning grounds (Bănărescu, 1964, Holcik, 1999, Bănărescu and Bănăduc, 2007). The species is vulnerable to water pollution and ambient temperature changes, and alteration in its proper habitat (Holcik 1999).

On the Romanian national territory the range of the Rhodeus amarus becomes more fragmented, especially in the last half of the century, due to the human impacts, which are different from one basin/basin sector to another and even in some protected areas (Ardelean and Wilhelm, 2007b, Battes et al., 2003, 2005, 2009, Bănăduc, 2001, 2005, 2007, 2008a, b; Bănăduc and Curtean-Bănăduc, 2013, Bănăduc et al., 2013, Bănărescu, 1964, Bănărescu and Bănăduc, 2007, Costiniuc and Gorgan, 2004, 
Costiniuc et al., 2006a, b; Florea and Contoman, 2014a, b, Oţel, 2007, Pintileasa et al., 2011, Pricope et al., 2001, Radu et al., 2008, Simalcsik et al., 2004, Telcean, 1999, 2010, Telcean and Bănărescu, 2002, Telcean and Cupșa, 2009a, b, Meșter et al., 2003, Momeu et al., 2009, Năstase et al., 2008, Năvodaru, 2004, Năvodaru and Năstase, 2006, Ureche, 2008, Ureche et al., 2010, 2013, Vornicu et al., 2006).

The current structural composition of the fish communities, including Rhodeus amarus, in the Natura 2000 site Oltul Mijlociu - Cibin - Hârtibaciu (ROSCI0132) shows decreased numbers as a result of historical continuous human impact. The distribution patterns of the fish communities and their abundance variation in this protected area reflects the associated effect of river habitat quality in the Olt River basin (Bănăduc 1999, 2000, 2001, 2005, Curtean-Bănăduc et al., 2007, CurteanBănăduc and Bănăduc 2001, 2004a, b, Curtean et al. 1999).

In a general context in which aquatic ecosystems become a priceless resource, the human impact on them is expected to increase (Curtean-Bănăduc and Bănăduc 2012).

In this context, no general management elements can be strictly used based on a copy paste approach in all protected areas due to the fact that different location conditions should be assessed and monitored, and only after that the appropriate management measures should be adapted and used for the local specific conditions.

Recently, process modeling techniques are increasingly being used to have "the big picture" of different systems/actions of any domain and also are used to facilitate understanding of the process steps for an efficient management. Modeling tools are software products that are used by analysts, business managers, or developers to create models of business organizations, to analyze models, and to save information about models and serve three primary functions. First, they document an existing situation. Second, they assist in analyzing the effects of possible changes. Third, they document plans to change the existing situation in some way. As a result they provide the ability to create various types of diagrams with valuable management elements. (Hall and Harmon, 2005)
The aims of the present research are: to highlight the current state of Rhodeus amarus population in the Natura 2000 site Oltul Mijlociu - Cibin - Hârtibaciu; to underline the current human pressures and threats; to reveal management measures for the preservation and improvement of the species conservation status with the help of management model based on specific requirements of the species and specific habitat indicators, as a management decision support system.

\section{STUDY AREA AND METHODS}

The Natura 2000 site Oltul Mijlociu - Cibin - Hârtibaciu, (24.324444 longitude, 45.682778 latitude, 2826.10 ha surface, $314 \mathrm{~m}$ minimum altitude, $568 \mathrm{~m}$ maximum altitude) is situated in Sibiu, Braşov and Vâlcea counties, a part of the Alpine and Continental biogeographic regions. The protected site was proposed also for ten fish species of the Habitats Directive (92/43/EEC) (*), (Rhodeus sericeus amarus Natura 2000 code 1134, Pelecus cultratus code 2511, Barbus meridionalis Natura 2000 code 1138, Cobitis taenia code 1149, Sabanejewia aurata code 1146, Gobio kessleri 2511, Zingel streber 1160, Zingel zingel 1159, Aspius aspius code 1130, Gobio uranoscpus code 1122).

Study area and river sectors where Rhodeus amarus individuals were sampled are shown in Fig. 1.

The fish individuals were sampled in 2011-2014 period, with specific fishing nets (active and/or passive fishing nets) and by electrofishing, followed by on site identification up to a species level, and an unharmed release immediately afterwards in their natural habitats.

The Rhodeus amarus species populations were monitored and their conservation status assessed in different sectors in relation to the human pressures and threats identified in this species habitats.

The fish populations status was assesses based on population size, balanced distribution of individuals on age classes, distribution area size, and percentage of individuals of the species of interest in the structure of fish communities.

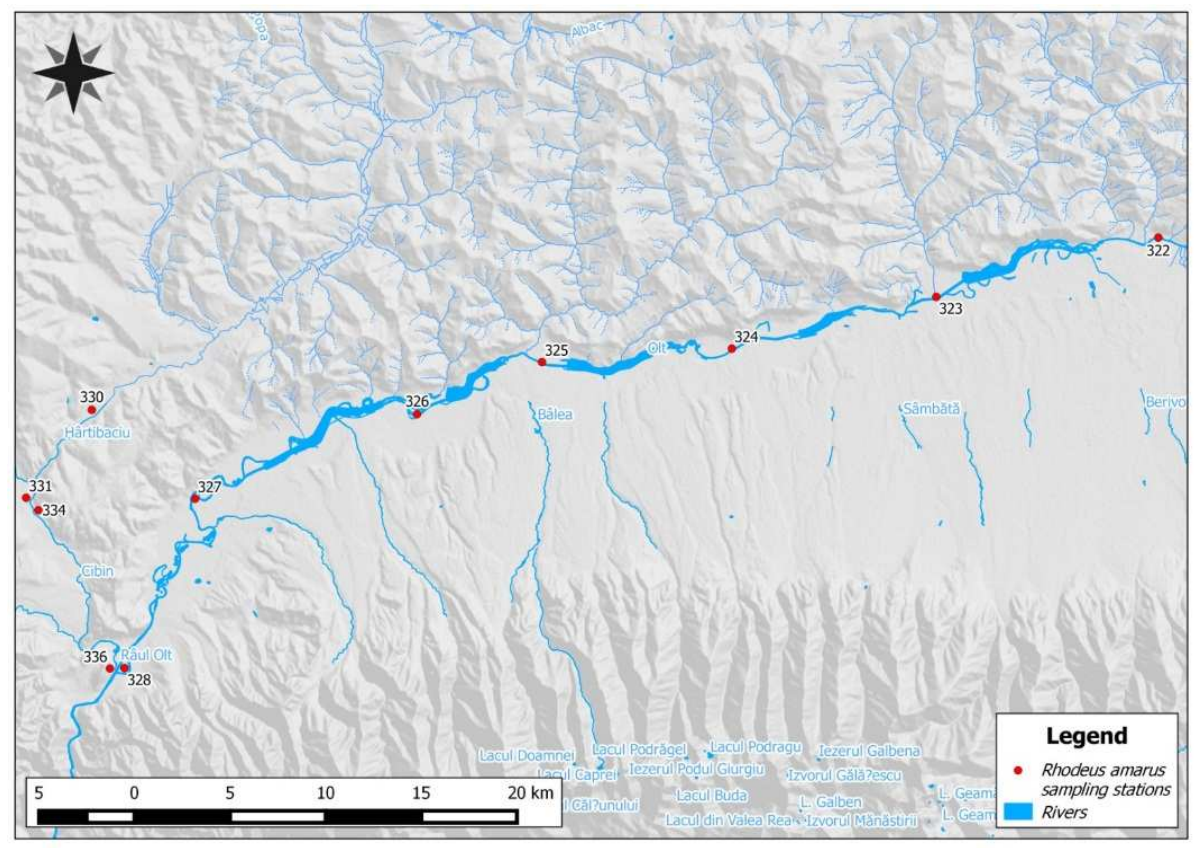

Figure 1. Rhodeus amarus individuals sampling stations: Cibin River 334 and 336, Hârtibaciu River 330 and 331 and Olt River 322 , 323, 324, 325, 326, 327 and 328 (Geographic Information System support Mr. Pătrulescu A.). 
The pressures, threats, and the specific species requirements were identified and selected in the field based on their relation to the fish communities' status.

In order to select the management measures that have to be taken to ensure the species favourable conservation status and illustrate the process, a management model was used. The model was ADONIS:CE, developed by Business Object Consulting. ADONIS: Community Edition is a free tool provided by the BOC Group which serves as a perfect entry point to professional Business Process Management and as a way to become familiar with ADONIS. ADONIS:CE is a functional and feature rich stand-alone version of ADONIS with some limitations in comparison to the commercial edition. BPMN (Business Process Model and Notation) is an international standardized modeling language used for the illustration of processes. Processes can be modeled simply, quickly and intuitively, using uniform notation (**). In Table 1 and Fig. 2, are extracted and explained the basic objects of ADONIS: CE (Hall and Harmon, 2005), used to model Rhodeus amarus species management.

\section{RESULTS AND DISCUSSIONS}

\section{Rhodeus amarus species populations state assessment}

The state of populations of Rhodeus amarus in the Olt River in the sectors 328, 327, 326, 325, 324 and 323 (Fig 1) was very good in conformity with: population size, balanced distribution of individuals on age classes, distribution area size, and a high percentage of individuals of the species of interest in the structure of fish communities. The exception is the sector 322 where the population state of the species was poor due to the poor habitat conditions. In the Olt River, the habitats in the sectors, in which the species was identified, were in an average condition, excepting sector 322 with a low condition.

The Rhodeus amarus population in the Cibin River in sector 334 (Fig 1) was low because of: population size, unbalanced distribution of the fish individuals on age classes, and a low percentage of the species individuals in the fish fauna. The characteristic habitat was in an average/low state. In sector 336 (Fig 1) the species was in very good state based on: population size, balanced distribution of the fish individuals on age classes, and a high percentage of individuals of species of interest in the fish fauna. In this sector, the characteristic habitat of the species of interest was in an average/good status.

The Rhodeus amarus population state in the Hârtibaciu River in the sectors 331 and 330 (Fig 1) was very good/good in conformity with: population size, balanced distribution of the individuals on age classes, and a high percentage of species individuals in the fish fauna structure. The habitats, where the individuals of this species were found, were in a good state.

\section{Current human preassures and threats}

In the Olt, Cibin and Hârtibaciu rivers, the following direct pressures on this fish species were identified: destroyng or significant reduction of habitats quality of watercourses due to regularization, pouching including in the reproduction period (April-August); and populations isolation/habitat fragmentation. The indirect pressure was the organic pollution, which caused restricted distribution of mollusc populations, on which the reproduction of Rhodeus amarus depends. The identified threats were: loss of habitat features (ponds in the floodplain, the river bends) due to hydraulic structures (accruals, embankments, ballast exploatation, water pollution, poaching through indiscriminate fishing methods).

\section{Rhodeus amarus specific requirements}

The adults need freshwater areas of rivers slowly flowing or stagnant, shallow, muddy bottom. The reproduction of this species individuals depends on the presence of these types of habitats, and also on the presence of mussels (Unio and Anodonta genera) because the female individuals lay their eggs in the mussel paleal cavity, where the larval development takes place (Holcik 1999, Bănărescu and Bănăduc, 2007).

\section{Specific habitat indicators}

Based on this species presence and abundance in the studied rivers, the following specific habitat indicators can be considered: areas in the river channel with a water depth less than $0.5 \mathrm{~m}(66 \%)$; weight muddy substrate (33-66\%); presence of dead branches and wetlands adjacent to the watercourses (10$33 \%)$; plant fragments percentage in the substrate/channel $(15 \%)$; percentage of slow-water surface $(66 \%)$.

\section{Management measures}

This fish species conservation status can be improved if some management measures will be inforced and maintained, such as: protect the river dead branches and wetlands adjacent to the watercourses; ban of fishing in the breeding period (AprilAugust); control of poaching, which is very intense and cquasipermanent, in all sectors of the rivers; maintain the liquid flow, the drain current regime, and a regime of relatively good oxygenation of the water, as well as avoid increasing of the amount of different pollutants in water in order to protect all molusks habitats essential for the reproduction of the fish species of interest; maintain the natural minor riverbedmeanders morphodynamics - meanders presence is important for molluscs living in the river bends where sediments (silt, sand) are more stable; preserve the natural vegetation corridors (arboreal, shrub and herbaceous) with a minimum width of 25$100 \mathrm{~m}$ on both sides of the water courses, vegetation debries are necessary to ensure the reproduction habitat quality; prohibit the waste abandonment of any kind in the river bed and wetland areas adjacent watercourses; avoid extracting sediments or disturbance by other means of minor riverbed substrate structure of small water courses, maintain of a minimum distance of five kilometers from every river bed mining sectors to the next one; implement integrated monitoring system including for the ichtyofauna.

\section{Site adapted management model}

The basic process for the on site management model is based on activities (squares) and decisions (triangles) (Figs. 2-4a-h).

In Table 1, are extracted and explained (from Hall and Harmon, 2005 - Version 1.1, November, 2005, http://mhcnet.com/whitepapers_presentations/2005 Process Trends (040306).pdf) the basic objects of ADONIS: CE, used to model the Rhodeus amarus species management:

In the left window of the program, you can see all the processes that are modeled as a table of contents (Figure 2). You can browse through them by a simple click. The same happens with the subprocesses created (e.g. Indicators, Management Measures for the first indicator). 


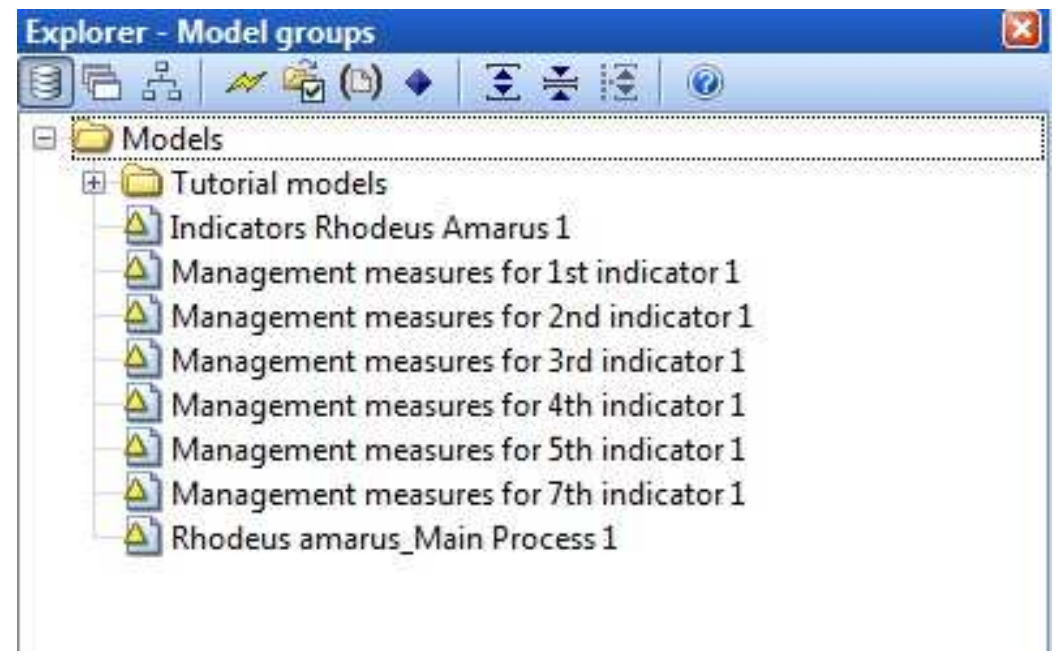

Figure 2. Content/structure of modeled processes.

Table 1. The 2005 Enterprise Architecture, Process Modelling and Simulation Tools Report, Version 1.1, November, 2005.

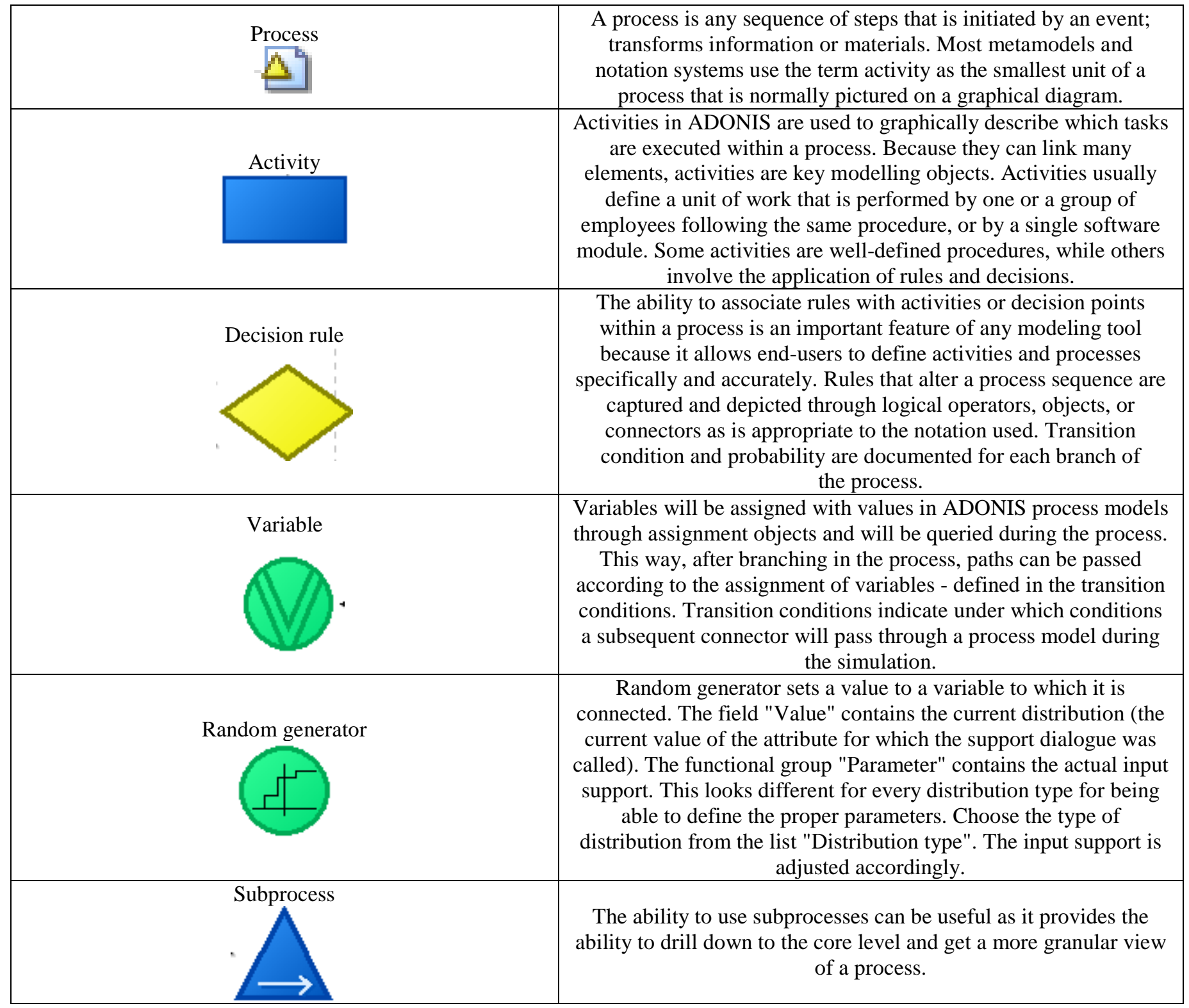




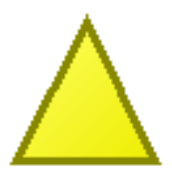

Rhodeus amarus

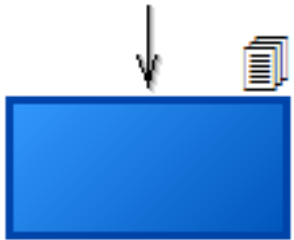

Specific

requirements

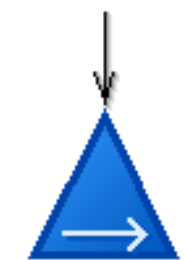

Indicators

Rhodeus amarus

2
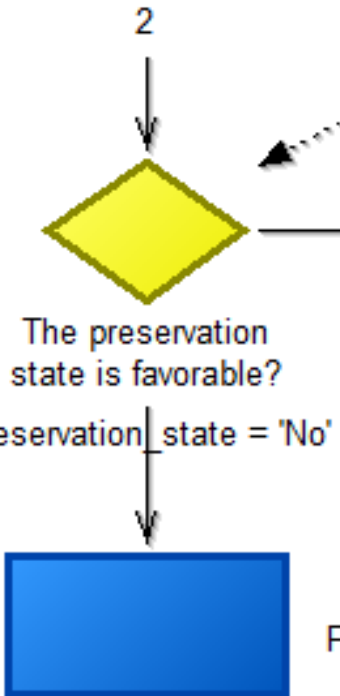

Preservation_state $=$ 'Yes'

Current

pressures on the

species

Discrete (Yes

0,$3 ;$ No 0,7 )

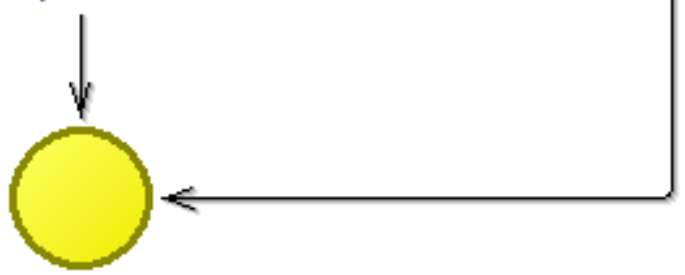

Edit the model attributes to display your copyright info

Powered by ADONIS:Community Edition www.adonis-community.com

Figure 3. Model of Rhodeus amarus species management - Main process / Starting process.

The basic process is called Model of Rhodeus amarus species and represents all the characteristics of the species: habitat specific requirements - can be accompanied by a document which explains these requirements, subprocess Indicators of the species - which contains all indicators, a decision on whether the conservation status is favourable. If the preservation state is in parameters, then the process ends. If the condition is not favourable, then the pressures on the species can be determined and the process ends. A variable and a generator can be assigned 
to every decision. The generator assigns a discrete variable that represents the probability of decision (e.g. If Preservation state
$=0.7$ we follow the branch "No" of the decision; if Preservation state $=0.3$, we follow the branch "Yes" of the decision).

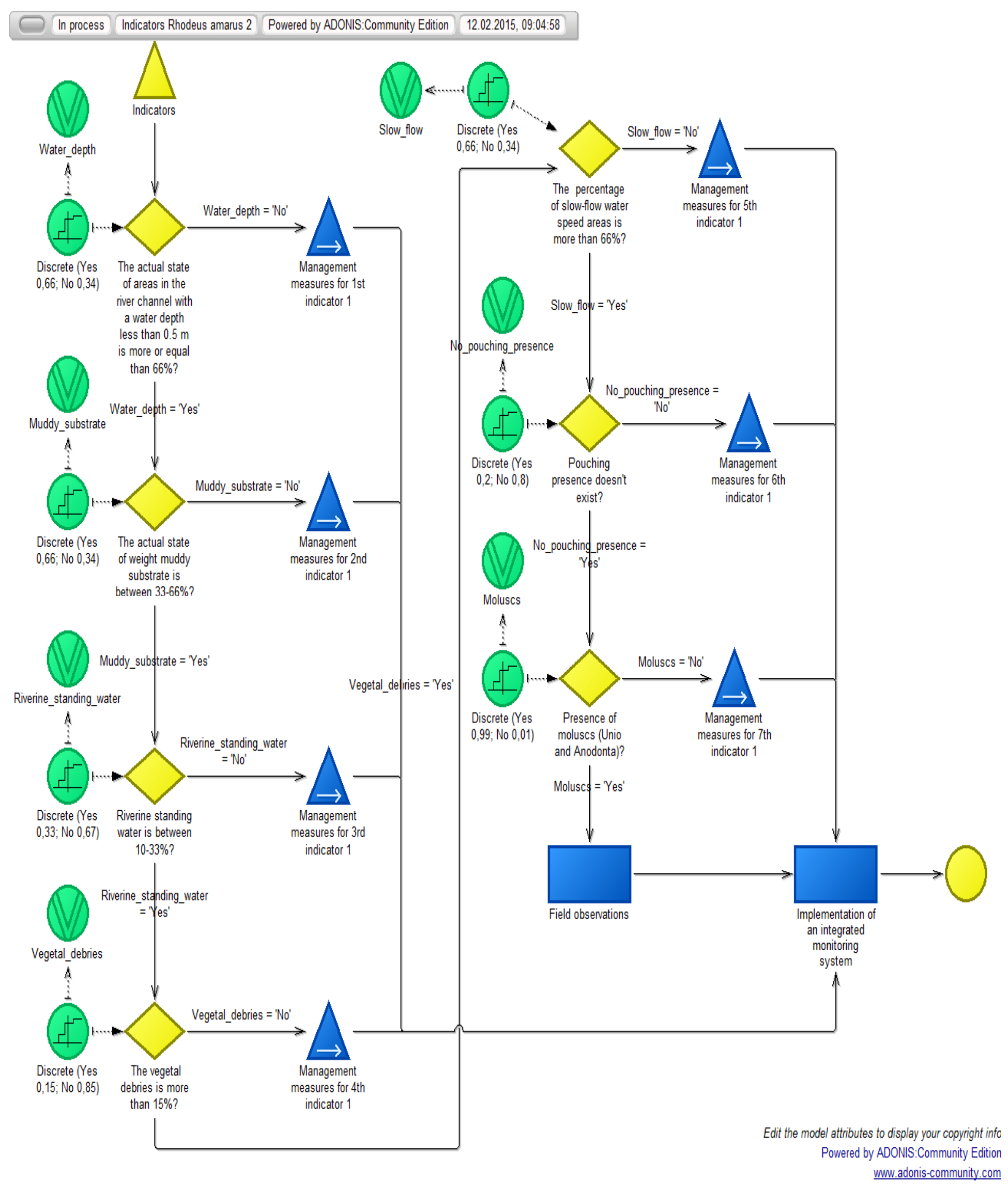

Figure 4. a: Model of current state for habitats of Rhodeus amarus vs. favourable preservation status indicators.

This model represents subprocess Indicators of the species Rhodeus amarus basic model and models all the indicators that we should consider for the species preservation. Depending on the probability in which they are found, we should take appropriate management measures (e.g. Management Measures indicator for $1 \mathrm{st}, 2 \mathrm{nd}$ and $7 \mathrm{th}$ ). If a condition indicator fulfils its 
standards, then the process goes from one indicator to another until the last activity, namely the implementation of an integrated monitoring system. If a condition indicator does not fulfil the standards, then certain management measures need to

\section{In process Management measures for 1st indicator}

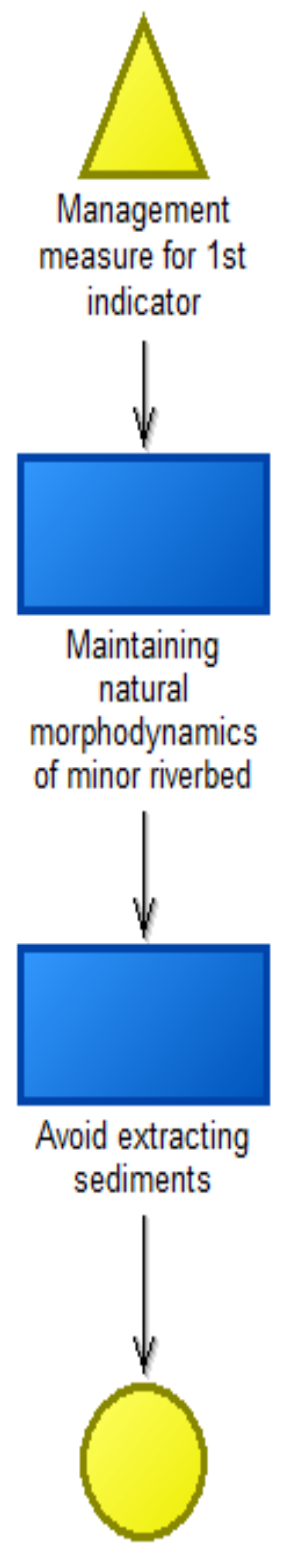

\section{Edit the model attributes to display your copyright info \\ Powered by ADONIS:Community Edition www.adonis-community.com}

Figure 4. b: Model of Management measures - the first indicator.

Each subprocess that provides management measures (Figures $4 \mathrm{a}-\mathrm{h})$ is modeled using only activities to facilitate the easy be taken for the welfare of the species. All these management measures are modelled as subprocesses in order not to load the model and to facilitate its understanding (Figures 4a-h).

In process Management measures for 2nd indicato

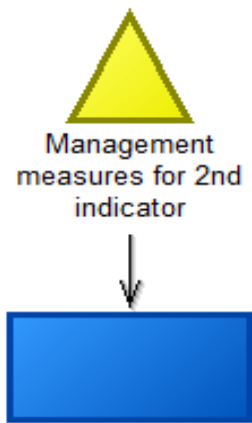

Protecting dead arms and wetlands

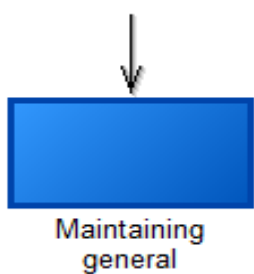

characteristic

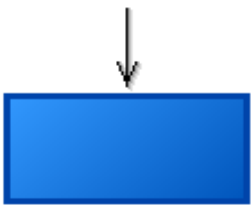

Maintaining natural morphodynamics of minor riverbed

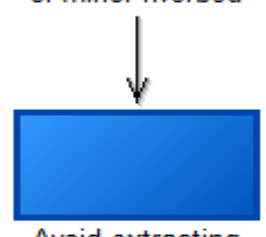

Avoid extracting sediments

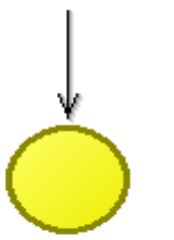

Edit the model attributes to display your copyright info Powered by ADONIS:Community Edition www.adonis-community.com

Figure 4. c: Model of Management measures - the second indicator.

understanding and visualization of the steps that must be taken in order to ensure the preservation of species indeed. 


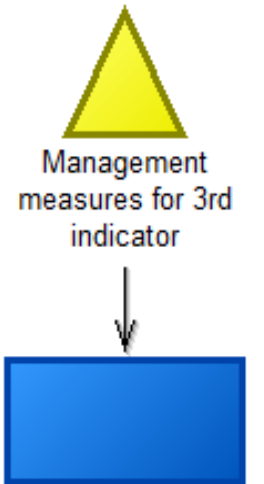

Protecting dead arms and wetlands

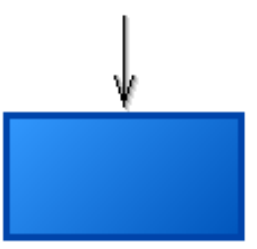

Maintaining general characteristics

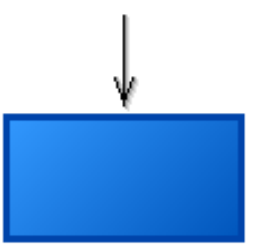

Maintaining natural morphodynamics of minor riverbed

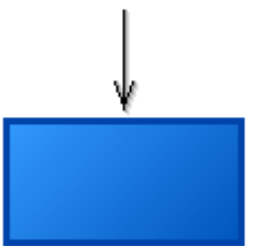

Preserving natural vegetation corridors

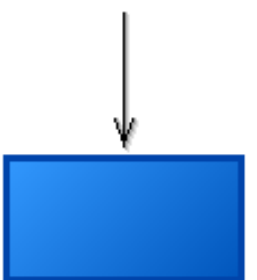

Avoid extracting sediments<smiles>CC1CCCCCCCC1</smiles>

Edit the model attributes to display your copyright info Powered by ADONIS:Community Edition www.adonis-community.com

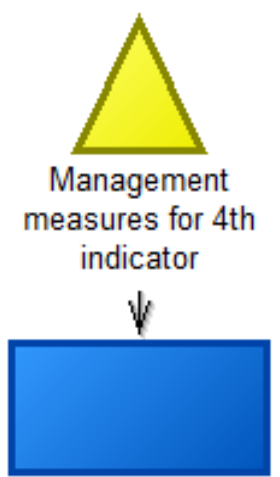

Protecting dead arms and wetlands

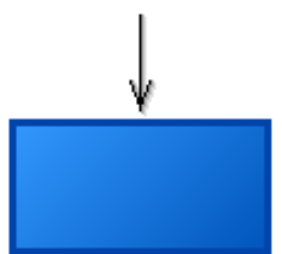

Maintaining natural morphodynamics of minor riverbed

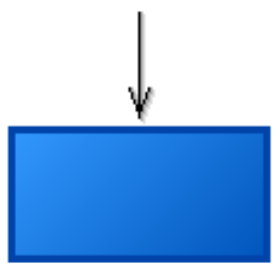

Preserving natural vegetation corridors

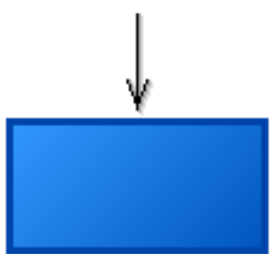

Avoid extracting

sediments

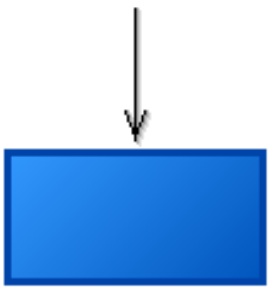

Pollution control

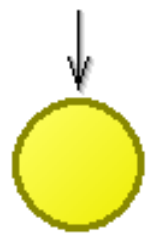

Edit the model attributes to display your copyright info Powered by ADONIS:Community Edition www.adonis-community.com

Figure 4. d: Model of Management measures - the third indicator. Figure 4. e: Model of Management measures - the fourth indicator. 


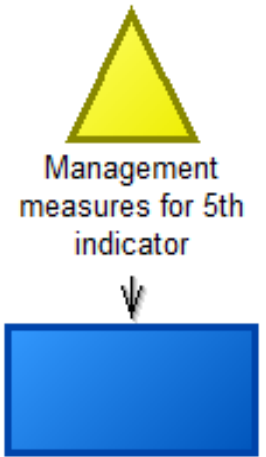

Protecting dead

arms and wetlands

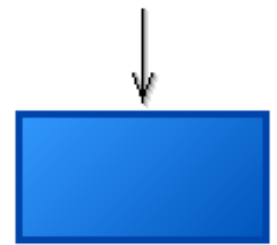

Maintaining general characteristics

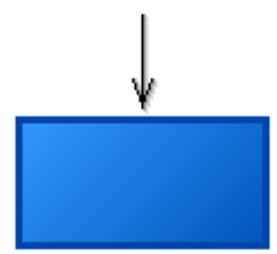

Maintaining

natural

morphodynamics

of minor riverbed

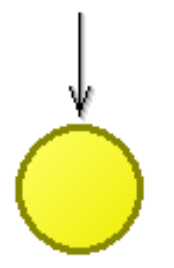

Edit the model attributes to display your copyright info

Powered by ADONIS:Community Edition www.adonis-community.com

Figure 4. f: Model of Management measures - the fifth indicator.

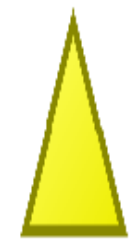

Management

measure for oth

indicator

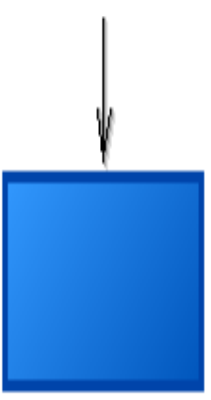

The breeding

period

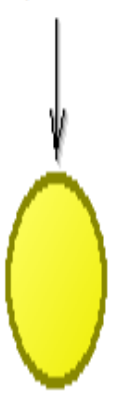

Edit the model attibutes to display your copyright info

Powered by ADONSS Community Edtition

unw. adonis-community.com

Figure 4. g: Model of Management measures - the sixth indicator. 

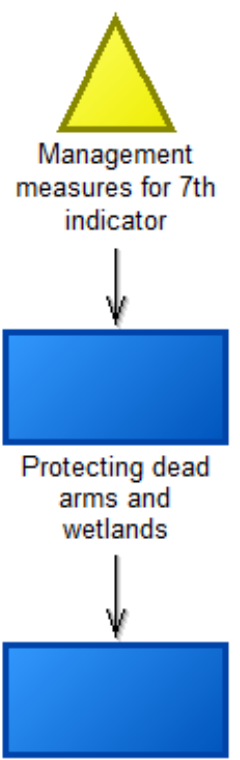

Maintaining

general

characteristics

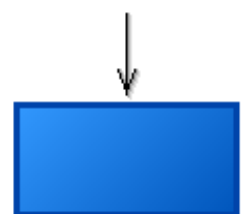

Maintaining

natural

morphodynamics

of minor river bed

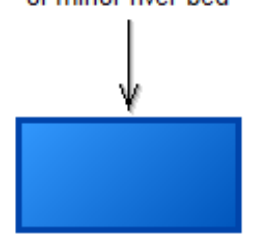

Prohibition of

waste

abandonment

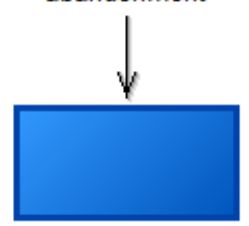

Avoid extracting

sediments

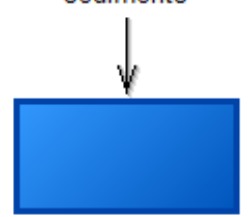

Pollution control

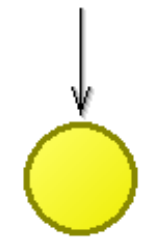

Edit the model attributes to display your copyright info Powered by ADONIS:Community Edition www.adonis-community.com

Figure 4. h: Model of Management measures - the seventh indicator. 


\section{CONCLUSIONS}

The current main threat to the Rhodeus amarus populations in the Natura 2000 site Oltul Mijlociu - Cibin - Hârtibaciu are the hydrotechnical modifications of the riverbeds, which induced the ecological state modification of this fish species and also of Unio and Anodonta species. At this threat it should to add chemical pollution and poaching.

The rivers Cibin, Hârtibaciu and Olt should be managed with the significant purpose of keeping a good chemical quality of the water.

The maintaining of the minor riverbed morphodynamics is very important - the meanders presence is very important for the local molluscs which are living in the inner $U$ shape parts of the river. The places, where the sediments (sand, mud) are relatively stable, provide suitable habitats for the molluscs important for the breeding of Rhodeus amarus.

The maintaining of the actual regimes of liquid flows and oxygenation, and avoidance of the increase in the sediments deposition rate in the water are necessary also for those mollusc species presence conservation.

The extraction of sediments in these rivers should be made in correspondence with their natural rate of refilling and at sites at a distance of minimum five $\mathrm{km}$ from each other.

In this paper, was presented the "big picture" of Rhodeus amarus species. ADONIS:CE was used here in ecology/biology domain, and we obtained a Rhodeus amarus model with all habitat species requirements, with indicators that provide favourable conservation status, with existing threats and pressures.

For further approaches, should be shaped such management systems for other fish species of conservative interest of Oltul Mijlociu - Cibin - Hârtibaciu Natura 2000 site.

\section{AKNOWLEDGEMENTS}

A part of these data were obtained in the European Union Structural Operational Programme Environment "Pentru Natură şi Comunităţile locale - Bazele unui management integrat Natura 2000 în zona Hârtibaciu-Târnava Mare-OLT" code SMIS CSNR 17049.

\section{REFERENCES}

1. Aldridge, D.C., (1999) Development of European bitterling in the gills of freshwater mussels. Journal of Fish Biology, 54: 138-151.

2. Ardelean, G. and Wilhelm, S. (2007) Polluting factors and their effects of the ichthyofauna of the Lăpuș Valley (Maramureș, Romania). Acta Ichtiologica Romanica, II, 17-24.

3. Bănăduc D., (1999) Data concerning the human impact on the ichthyofauna of the upper and middle sectors of the Olt River, Transylvanian Review of Systematical and Ecological Research, 1, Editura Universităţii "Lucian Blaga" din Sibiu, ISSN 1841-7051, ISBN 973-9410-69-3, pp. 157-164.

4. Bănăduc, D., (2000) Ichthyofaunistic criteria for Cibin River human impact assesment, Travaux du Museum National d Histoire naturelle Grogore Antipa, București, p. 365-372, vol. XLII..

5. Bănăduc, D. (2010), New SCIS proposal regarding the ichthyofauna after the Pannonian Biogeographic Seminar for Romania, Sibiu (Transylvania, Romania) 9-12 June 2008, Acta Oecologica Carpatica, III, p. 117-122.
6. Bănăduc, D. (2011) New SCIS proposal regarding the ichtiofauna after the Alpine Biogeographic Seminar for Romania, Sibiu (Transylvania, Romania) 9-12 June 2008, Acta Oecologica Carpatica, p. 199-208, IV, 2011

7. Bănăduc, D. and Curtean-Bănăduc, A., (2013) - New SCIs proposal regarding the ichthiofauna for the Stepic Biogeographic area in Romania, Acta Oecologica Carpatica, VI, 137-148.

8. Bănăduc, D. (2005) Fish associations - habitats quality relation in the Târnave rivers (Transylvania, Romania) ecological assessment, Transylv. Rev. Syst. Ecol. Res. 2, (2005), "The Târnava River Basin", 123-136.

9. Bănăduc, D., (2007b) Middle Olt River (Transylvania, Romania) - Special area for conservation (Natura 2000 Site) proposal for Barbus meridionalis Risso, 1827 and associated fish species, Acta Ichtiologica Romanica, II, 3742.

10. Bănăduc, D., Stroilă, V. and Curtean-Bănăduc, A., 2013 The fish fauna of the Timiş River (Banat, Romania), Transylvanian Review of Systematical and Ecological Research, 15, 145-172.

11. Bănăduc, D. (2001) Specii de peşti dulcicoli şi migratori în mediul dulcicol, de interes comunitar, prezente în România, în Natura 2000 în România. Conservarea speciilor şi habitatelor acvatice, coordonator Curtean-Bănăduc Angela, Editura Alma Mater Sibiu, ISBN 973-632-243-2, p 72-81.

12. Bănăduc, D. (2007a) Fish of Natura 2000 network interest in Romania, in Romanian NATURA 2000 NGO Coalition contribution for the SCIs designation, editori Curtean Bănăduc Angela, Florescu Florentina, Editura Alma Mater Sibiu, ISBN 978-973-632-402-4.

13. Bănăduc, D. (2008a) Natura 2000 sites proposals regarding the fish species of Community interest in the Romanian Alpine Biogeographical Regon, Transylvanian Review of Systematical and Ecological Research, 6, Editura Universităţii "Lucian Blaga" din Sibiu, ISSN 1841-7051, p. 185-196.

14. Bănăduc, D. (2008b) Natura 2000 sites proposals regarding the Europen Community interest fish (Cyclostomata) species (Romania), Acta Oecologica Carpatica, Vol. I, p. 83-88.

15. Bănăduc, D., Nagy A., and Curtean-Bănăduc A. (2012) New SCIS proposal regarding the ichtiofauna after the Continental Biogeographic Seminar for Romania, Sibiu (Transylvania, Romania) 9-12 June 2008, Acta Oecologica Carpatica, p. 145-158, V.

16. Bănărescu, P. M., (1964) Pisces-Osteichthyes, Fauna R. P. R., vol. XIII., Edit. Academiei R. P. R., Bucureşti, p. 962.

17. Bănărescu, P. M. and Bănăduc, D, (2007), Habitats Directive (92/43/EEC) fish species (Osteichthyes) on the Romanian Territory, Acta Ichtiologica Romanica, II, p. 4378.

18. Battes, K.W., Pricope, F., Ureche, D. and Stoica I., (2009) Ichthyofauna status from the Suceava catchment area from 2001 to 2005, Studii şi cercetări Ştiinţifice, Biologie, Seria biologie animală, Vol. 17, 59-67.

19. Battes, K.W., Pricope, F., Ureche, D., Stoica, I., (2005) Ichthyofauna status in the Siret catchement area, with emphasis on the effect of the January 2001 pollution, Analele Ştiinţifice ale Univ. „Al. I. Cuza”, Iaşi, secţiunea I Biologie animală, Tom LI, 2005, Ed. Univ. „Al. I. Cuza” Iaşi, 123-143.

20. Battes, K.W., Pricope, F., Ureche, D. and Stoica I., Palaghiţă, D., (2003) Prospective monitoring on fish communities from the Bîrlad catchement area, 
Universitatea din Bacău, Studii şi Cercetări Ştiinţifice, Biologie, Serie nouă, Vol. 8, 102-108.

21. Costiniuc, C. D., Davideanu, G. and Davideanu, A. (2006a) Data concerning the fish communities of the Jijia River (Romania), Acta Ichtiologica Romanica, I, 55-64.

22. Costiniuc, C. D., Davideanu, G. and Davideanu, A., (2006b) Some data concerning the fish communities of the Bahlui River (Romania), Acta Ichtiologica Romanica, I, 65-74.

23. Costiniuc, C. D. and Gorgan, L. D., (2004) Researches about Tansa-Belcești lake's ihtiofauna, Analele Ştiinţifice ale Univ. „Al. I. Cuza”, Iaşi, secţiunea I Biologie animală, Tom L, 2004, Ed. Univ. „Al. I. Cuza” Iaşi, 215-221.

24. Curtean, A., Sîrbu, I., Drăgulescu, C., Bănăduc, D., (1999) Impactul antropic asupra biodiversităţii zonelor umede din bazinul superior şi mijlociu al Oltului, Editura Universităţii "Lucian Blaga" din Sibiu, ISBN 973- 651-003-4, 102 p.

25. Curtean-Bănăduc, A., Bănăduc, D. (2012) Aspecte privind impactul deversării apelor uzate asupra sistemelor ecologice lotice receptoare, în Apa resursă fundamentală a dezvoltării durabile. Metode şi tehnici neconvenţionale de epurare şi tratare a apei, Vol. II, coordonator Oprean L., Editura Academiei Române, pp. 393 - 416.

26. Curtean-Bănăduc, A., Bănăduc D. (2004b) Aspecte privind dinamica faunei râului Cibin în ultimii 150 de ani, Studii şi Comunicări, Muzeul Brukenthal Sibiu, Ştiinţele Naturii, vol. 29, ISSN 1454-4784, pp. 205 - 214.

27. Curtean-Bănăduc A., Bănăduc D., Bucşa C. (2007) Watershed Management (Transylvania, Romania) implications, risks, solutions, Strategies to Enhance Environmental Security in Transition Countries, NATO Security trough Science Series - C: Environmental Security, Springer, pp. 225 - 238, ISBN 978-1-4020-59957.

28. Curtean-Bănăduc A., Bănăduc D. (2001) Cibin River (Transylvania, Romania) management, scientific foundation proposal, Acta oecologica, Vol. VIII, Nr. 1-2, Editura Universităţii "Lucian Blaga" din Sibiu, ISSN 12215015, pp. $85-100$.

29. Curtean-Bănăduc A., Bănăduc D. (2004a) Cibin River fish communities structural and functional aspects, Studii şi Cercetări Ştiinţifice - Seria Biologie, Universitatea din Bacău, vol. 9, ISSN 122-919-X, pp. 93 - 102.

30. Curtean-Bănăduc, A., Bănăduc, D. (2008) Natura 2000 sites proposals regardingthe fish species $f$ Community interest in the Romanian Panonian Biogeographical Region, Acta oecologica cibiniensis, Vol. I, Editura Universităţii "Lucian Blaga" din Sibiu, ISSN 1221-5015, p. $75-95$

31. Hall, C., Harmon, P., (2005) The Enterprise Architecture, Process Modeling \& Simulation Tools Report, Version 1.1 (2005) November, 2005, http://mhcnet.com/whitepapers_presentations/2005 Process Trends (040306).pdf)

32. Florea, L. Contoman, M., (2014a) Speciile de pești de interes comunitar din fluviul Dunărea, Volumul Simpozionului Internaţional „Sustainable use and protection of animal world diversity", Chisinau, 30-31 oct. 2014, ISBN 978-9975-62-379-7, p. 2007-2009

33. Florea, L. Contoman M., (2014b) Inventarierea Peștilor din Parcul Natural Balta Mică a Brăilei, Volumul Simpozionului Internaţional „Sustainable use and protection of animal world diversity", Chisinau, 30-31 oct. 2014, ISBN 978-9975-62-379-7, p 2009-2011

34. Holcik, J., (1999). Rhodeus sericeus (Pallas, 1776). In Bănărescu, P. M. (Ed.), The Freshwater Fishes of Europe,
Vol. 5/1, Cyprinidae 2/1. AULA-Verlag, Wiebelsheim, 132.

35. Meșter, L., Crăciun, N., Aioanei, F., Ureche, D. (2003) Research on the fish fauna in the Argeş, Neajlov, Sabar, Ialomiţa, Dâmboviţa and Colentina River Basins, Universitatea din Bacău, Studii şi Cercetări Ştiinţifice, Biologie, Serie nouă, Vol. 8, 140-153.

36. Momeu, L, Battes, K., Battes, K., Stoica, I., Avram, A., Cîmpean, M., Pricope, F, and Ureche, D., (2009) Algae, macroinvertebrate and fish communities from the Arieș River Catchment area (Transylvania, Romania), Transylv. Rev. Syst. Ecol. Res. 7, "The Arieş River Basin", 151-182.

37. Năstase, A., Năvodaru, I. Cernișencu, I., 2008 Comparative data of ichthyodiversity from SomovaParcheș complex lakes (Romania), Acta Ichtiologica Romanica, III, 93-104.

38. Năvodaru, I. and Năstase, A., (2006) Ichthyofauna of River Danube Delta: Gorgova - Uzlina and Şontea - Furtuna lakes complexes, Acta Ichtiologica Romanica, I 185-202.

39. Năvodaru I., (2004) Possibilities of ecological and ichthyofaunistic reestablishments of the former easily flooded region of the Danube - the Călărași Island - Bala, Studia Univ. Vasile Goldiș, Seria Șt. Vieții, vol. 14, 93-99.

40. Oţel V., (2007) The present status of the fish species considered of community and national interest, in the Danube delta Biosphere Reserve, Romanian sector, Acta Ichtiologica Romanica, II, 177-188.

41. Pintilieasa R., Ureche D., Ureche C. (2011) Status of the fish communities in the upper basin of River Mureș in 2009, Studii și cercetări științifice, Biologie, Seria biologie animală, 20 (2): 158-165.

42. Pricope, F., Battes, K. W., Ureche, D., (2001) Monitorizarea ihtiofaunei din bazinul superior al râului Suceava şi Moldova, Buletin Ştiinţific, Seria B, Vol. XIV, Fasc. Chimie-Biologie, Universitatea de Nord Baia-Mare, 143-150.

43. Radu, G. A., Meliceanu, I. and Patriche, N., 2008 Ichthyofauna, an important heritage of the lower Prut floodplain (Moldova, Romania), Acta Ichtiologica Romanica III, pp. 137-146.

44. Simalcsik, F., Misăilă, E. R., Misăilă C., Pricope F., (2004) The effect of Rivers' pollution with cellulosic and municipal used waters in ichtyofauna's integrity, Studia Univ. Vasile Goldiș, Seria Șt. Vieții, vol. 14, 135-140.

45. Smith, C. M., Reichard, P., Jurajda Przybylski M., (2004) The reproductive ecology of the European bitterling (Rhodeus sericeus). Journal of Zoology, p. 262: 107-124.

46. Telcean, I., Bănărescu P., (2002) Modifications of the fish fauna in the upper Tisa river and its southern and eastern tributaries, in Tiscia Monograph Series 6 Ecological aspects of the Tisa River Basin (Sarkany A and Hamar J. eds.) pp 179-186.

47. Telcean, I., (1999) Starea naturală a văilor din bazinul Crişurilor, Fluvii Carpatorum, Sarkany-Kiss E., Sîrbu I., Kalivoda B., eds. Szolnok-Tg. Mureș, pp. 227-233.

48. Telcean, I., (2010) Notă asupra ihtiofaunei canalului colector al Crişurilor şi a bălţilor învecinate, Ocrotirea naturii. Serie nouă, tom 46, pp 119-123, Ed. Acad. Rom.

49. Telcean, I., Cupşa D., (2009a) The backwaters and drainage canals as natural refuges for the lowland rivers' fishfauna (Someş, Crişuri, Mureş - North-Western Romania) Biharean Biologist Vol. 3, No.1, Pp.37-44.

50. Telcean, I., Cupşa, D., (2009b) Fishfauna from the lowland Mureş River and the Floodplain Natural Park area 
(Western-Romania), Analele Universităţii din Oradea, Fascicula de Biologie, Tom XVI, 2009, pp 132-136.

51. Ureche, D. (2008) Studii ecologice privind ihtiofauna din bazinul mijlociu şi inferior al râului Siret, Editura PIM, Iaşi, $223 \mathrm{pp}$.

52. Ureche, D., Pintilieasa R., Ureche C., Voicu R. E., (2013). Researches on the fish communities in the middle basin of River Mureș in 2009-2011, Analele Ştiinţifice ale Univ. "Al. I. Cuza" Iaşi, secţiunea I Biologie animală, Supliment 2011, Ed. Univ. "Al. I. Cuza" Iaşi, 127-136.

53. Ureche, D., Ureche C., Nicoară M., Plăvan G., (2010) The role of macroinvertebrates in diets of fish in River
Dâmbovița, România, Verh. Internat. Verein. Limnol., 30 (10): 1582-1586.

54. Vornicu B., Davideanu G. and Davideanu A., (2006) Data concerning the fish communities of the Moldova River (Romania), Acta Ichtiologica Romanica, I, 293-304.

55. * (1992) Council Directive 92/43/EEC of 21 May 1992 on the conservation of natural habitats and of wild fauna and flora. http://eur-lex.europa.eu/legal-content/EN/TXT/?uri $=$ CELEX:31992L0043

56. $* * \quad \mathrm{http}: / / \mathrm{www}$.boc-group.com/products/adonis/bpmnmethod/ 